ZOOLOGIA 30 (6): 661-668, December, 2013

http://dx.doi.org/10.1590/S1984-46702013005000005

\title{
A new genus, Atlanteuptychia gen. nov., for Euptychia ernestina (Lepidoptera: Nymphalidae: Satyrinae)
}

\author{
André V. L. Freitas ${ }^{1,3}$, Eduardo P. Barbosa1, Jessie P. Santos ${ }^{1} \&$ Olaf H. H. Mielke² \\ 1 Departamento de Biologia Animal and Museu de Zoologia, Instituto de Biologia, Universidade Estadual de Campinas. Caixa \\ Postal 6109, 13083-970 Campinas, SP, Brazil.E-mail: baku@unicamp.br; ed_1482@yahoo.com.br; jessiepereira@gmail.com \\ ${ }_{2}^{2}$ Departamento de Zoologia, Universidade Federal do Paraná. Caixa postal 19020, 81531-980 Curitiba, PR, Brazil. \\ ${ }^{3}$ Corresponding author.
}

\begin{abstract}
Atlanteuptychia Freitas, Barbosa \& Mielke, gen. nov. is proposed for Euptychia ernestina Weymer, 1911 and illustrated. This taxon lacks the posterior projection of the tegumen, a synapomorphy of Euptychia Hübner, 1818, and does not share morphological synapomorphies with Cyllopsis R. Felder, 1869 and Paramacera Butler, 1868, two Central American genera apparently closely related to Euptychia ernestina, based on molecular data. This evidence supports the proposition of a new genus endemic to the Atlantic Forest, A. ernestina stat. nov.
\end{abstract}

KEY WORDS. Atlantic Forest; butterfly; Euptychiina; Satyrini.

With over 400 described species, the subtribe Euptychiina (Nymphalidae: Satyrinae: Satyrini) is mostly Neotropical, with a single species in the Nearctic region and one in Southeast Asia (Lamas 2004a, PeÑa et al. 2006, 2010, Marín et al. 2011). Euptychia Hübner, 1818, formerly including most Neotropical Euptychiina, now includes only 16 described species of small satyrines, typical of wet forests, predominantly in the Andeans foothills and in the Amazon region (DeVries 1987, Lamas 2004b, Brévignon 2005, Pulido et al. 2011, Freitas et al. 2012). Although its position within the Euptychiina is still unclear, Euptychia is a welldefined clade, supported by morphological and molecular data (Peña et al. 2006, 2010, Peña \& Wahlberg 2008, Freitas et al. 2012).

Euptychia ernestina Weymer, 1911 was originally described in Euptychia, where it remained until recently, mainly because of its superficial resemblance to some bona fide Euptychia (Weymer 1911). Freitas et al. (2012), based on molecular and morphological evidence, suggested that this taxon should be removed from Euptychia. In particular, E. ernestina lacks the conspicuous posterior projection of the tegumen above the uncus, a synapomorphy of all known Euptychia (Freitas et al. 2012). In fact, molecular data show not only that E. ernestina is not part of the Euptychia clade, but also that this taxon is part of a clade which includes the Central American Cyllopsis R. Felder, 1869 and Paramacera Butler, 1868 (PeÑa et al. 2006, 2010).

In this contribution we propose a new genus for Euptychia ernestina and provide a detailed morphological description of this species.

\section{MATERIAL AND METHODS}

Specimens of E. ernestina were studied and collected in the field in six localities in Southeastern Brazil: 1) Vale do Rio
Quilombo, Santos, São Paulo ( $\left.\left.23^{\circ} 48^{\prime} \mathrm{S}, 46^{\circ} 18^{\prime} \mathrm{W}, 50-200 \mathrm{~m}\right), 2\right)$ Morro Grande, Cotia, São Paulo ( $23^{\circ} 42^{\prime}$ S, 46 $6^{\circ} 59^{\prime} \mathrm{W}, 850-950$ $m)$, 3) Estação Biológica de Boracéia, Salesópolis, São Paulo $\left(23^{\circ} 39^{\prime} \mathrm{S}, 45^{\circ} 53^{\prime} \mathrm{W}, 850 \mathrm{~m}\right)$, 4) DAE Dam, Serra do Japi, Jundiaí,

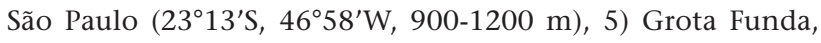

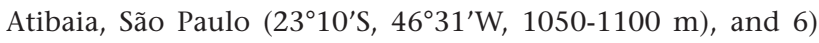
Reserva Ecológica de Guapiaçu, Cachoeiras de Macacu, Rio de Janeiro $\left(22^{\circ} 27^{\prime} \mathrm{S}, 42^{\circ} 46^{\prime} \mathrm{W}, 1000 \mathrm{~m}\right)$.

Additional data on E. ernestina deposited in museums were obtained from seven collections. The acronyms for the collections are: BMNH - The Natural History Museum, London, England; DZUP - Departamento de Zoologia, Universidade Federal do Paraná, Curitiba, Paraná, Brazil; DZUP-OM “Coleção Olaf H. H. Mielke", Curitiba, Paraná, Brazil; MNRJ - Museu Nacional, Universidade Federal do Rio de Janeiro, Rio de Janeiro, Rio de Janeiro, Brazil; MZSP - Museu de Zoologia, Universidade de São Paulo, São Paulo, Brazil; USNM - National Museum of Natural History, Smithsonian Institution, Washington, DC, USA; ZUEC - Museu de Zoologia da Universidade Estadual de Campinas, Unicamp, Campinas, São Paulo, Brazil. Additional data of sightings of the species in the field were kindly provided by Keith S. Brown Jr from several unpublished butterfly records.

Dissections were made using standard techniques. Legs, palp and abdomen were soaked in warm 10\% potassium hydroxide for nearly 10 minutes before dissection. Dissected parts were stored in glycerol. In order to be able to see the venation, we soaked the wings in alcohol and $\mathrm{NaClO}$ solution (bleach) to dissolve the scales. The taxonomic nomenclature follows Lamas (2004a), modified by PeÑa et al. (2006) and WAhlberg et al. (2009). Drawings and measurements of wings, legs and palp were made using a Leica ${ }^{\circledR}$ MZ7.5 stere- 
omicroscope equipped with a micrometric scale and a drawing tube. Photographs of the male and female genitalia were taken using a Zeiss Discovery V20 Stereomicroscope. The following abbreviations were used: (FW) forewing, (HW) hind wing, (D) dorsal, (V) ventral.

\section{TAXONOMY}

\section{Atlanteuptychia Freitas, Barbosa \& Mielke gen. nov.}

Type species. Euptychia ernestina Weymer, 1911

Diagnosis. Eyes naked, dark brown with a light brown basal stripe. Palpus approximately 2.0 times longer than head height, covered with short, light yellow and long dark hairs (Fig. 3). Antenna 8.0-9.0 $\mathrm{mm}$ long, extending to mid-costa, with 29 to 32 segments; shaft dark brown with the internal margin bearing white dots; club composed of 10-11 segments, well developed, 3-4 of which are yellow in their middle section (Fig. 4). Legs covered with dark brown scales on femur and light yellow scales on tibia and tarsus.

Male genitalia (Figs 7-10): Saccus short; tegumen rounded; gnathos long and pointed, curved upwards; uncus elongated and pointed distally; valvae elongated, trapezoidal, with a pointed distal extremity, internal margin with a series of small teeth; aedeagus straight; cornuti absent; fultura inferior membranous.

Female genitalia (Figs 11-12): Papillae anales long and hairy, adorned with few setae, ductus bursae short and slightly sclerotized; corpus bursae ellipsoidal with two long sclerotized parallel signa running along the entire length of corpus bursae.

Etymology. The generic name refers in part to the Atlantic region of Brazil, to which the taxon is endemic, in addition to its relationship to other genera in Euptychiina.

Type and only species: Atlanteuptychia ernestina (Weymer, 1911), comb. nov.

Remarks. Among the genera with similar wing color patterns, Atlanteuptychia gen. nov. can be easily distinguished from Euptychia Hübner, 1818 by the absence of the posterior projection of the tegumen and by the presence of a well-developed gnathos in the male genitalia, and by the absence of a recurrent vein in the FW discal cell. The new genus differs from Cissia Doubleday, 1848 by the short saccus and gnathos (both usually longer in most Cissia); and from Carminda Dias, 1998 by the slightly wavy margin of the HW (strongly wavy in Carminda), and by the shape of the uncus in dorsal view (laterally extended in Carminda); differs from all species of the above three genera by the presence of a conspicuous androconial tuft of long hairs on the male HWD in space $\mathrm{CuA}_{2}-2 \mathrm{~A}$, and by having the last two abdominal segments dorsally covered with distinct black scales.

\section{Atlanteuptychia ernestina comb. nov. Figs 1-18}

Euptychia ernestina Weymer, 1911: 206, pl. 47, lectotype female, [Santa] Leopoldina, Espir.[ito] Santo, Bras.[ilien], 1894. [Julius] Michaelis (deposited in Museum für Naturkunde, Humboldt Universität [MNHU], Berlin, Germany), herein designated by G. Lamas (examined in1994); GAEDE 1931: 446; D’Abrera 1988: 773, 874; Brown \& Freitas 2000: 85, 104; Lamas 2004b: 219; Uehara-Prado et al. 2004: 14, 24, pl. 9, 2007: 49, fig. 5 (code Eern); PeÑa et al. 2006: 35, 39, 40, 44, figs 1, 2, 6; PeÑa et al. 2010: 247, 250, 251, 252, 253, 254, figs 2, 3, 4; Francini et al. 2011: 65; Freitas et al. 2012: 466. The name Euptychia ernestina was established by WeYMER (1911) based on an unstated number of specimens from "Esperito [sic] Santo (Brasilien)". The lectotype has been designated to fix the identity of the name.

Redescription. Male (Figs 1-6). Body entirely dark brown. Last two abdominal segments dorsally covered with distinct black scales (Figs 5 and 6). FW length 16.0-19.0 $\mathrm{mm}(\mathrm{n}=5)$; HW length 15.0-16.0 mm ( $\mathrm{n}=5)$. Dorsal ground color of both wings brown with few markings; dark sub marginal stripe especially conspicuous in HW; well-defined androconia comprising long, dark hair-like scales in space $\mathrm{CuA}_{2}-2 \mathrm{~A}$ on the HWD (Figs 1 and 5). Ventral color of both wings brown with several markings as following: FWV crossed by two weakly marked dark brown lines, first line extended from Sc, crossing discal cell to half the space $\mathrm{CuA}_{2}-2 \mathrm{~A}$ one third from base; second line, broader, extended from costa to half the space $\mathrm{CuA}_{2}-2 \mathrm{~A}$ two-thirds from the wing base; dark brown zigzagging sub marginal line and a brown regular marginal line extending from costa to $2 \mathrm{~A}$; apical region light, covered with cream scales, with well-developed dark ocellus in space $\mathrm{R}_{5}-\mathrm{M}_{1}$ complete, outlined by yellow ring, and with silver pupil; two to three additional irregular weakly marked silver ocelli without the black areas and with incomplete yellow outline apparent in most examined individuals are usually present in space $\mathrm{M}_{1}-\mathrm{M}_{2}$ and $\mathrm{M}_{2}-\mathrm{M}_{3}$. HWV with dark brown region in basal area near insertion of wings; crossed by two dark brown irregular lines from costa to anal margin delimiting lighter area, first line more regular, one third from wing base; second lines irregular in shape and thickness, two-thirds from wing base; margin light brown, with dark brown irregular zigzag sub marginal line and brown regular marginal line extending from costa to $2 \mathrm{~A}$; series of five ocelli present in spaces Rs- $\mathrm{M}_{1}$ (ocellus 1), $\mathrm{M}_{1}-\mathrm{M}_{2}$ (2), $\mathrm{M}_{2}-\mathrm{M}_{3}$ (3), $\mathrm{M}_{3}-\mathrm{CuA}_{1}$ (4), $\mathrm{CuA}_{1}$ $\mathrm{CuA}_{2}$ (5); ocelli 1, 2 and 5 complete, black, outlined by yellow ring, and with silver pupil; ocelli 3 and 4 irregular in shape, silver, without black areas and with incomplete yellow outline. Wing venation, palpus and foreleg of male are illustrated in Figs 13, 15, and 16, respectively.

Female. FW length $19.0 \mathrm{~mm}(\mathrm{n}=2)$. HW length 15.0$16.0 \mathrm{~mm}(\mathrm{n}=2)$. Except by the absence of patch of dark scales 

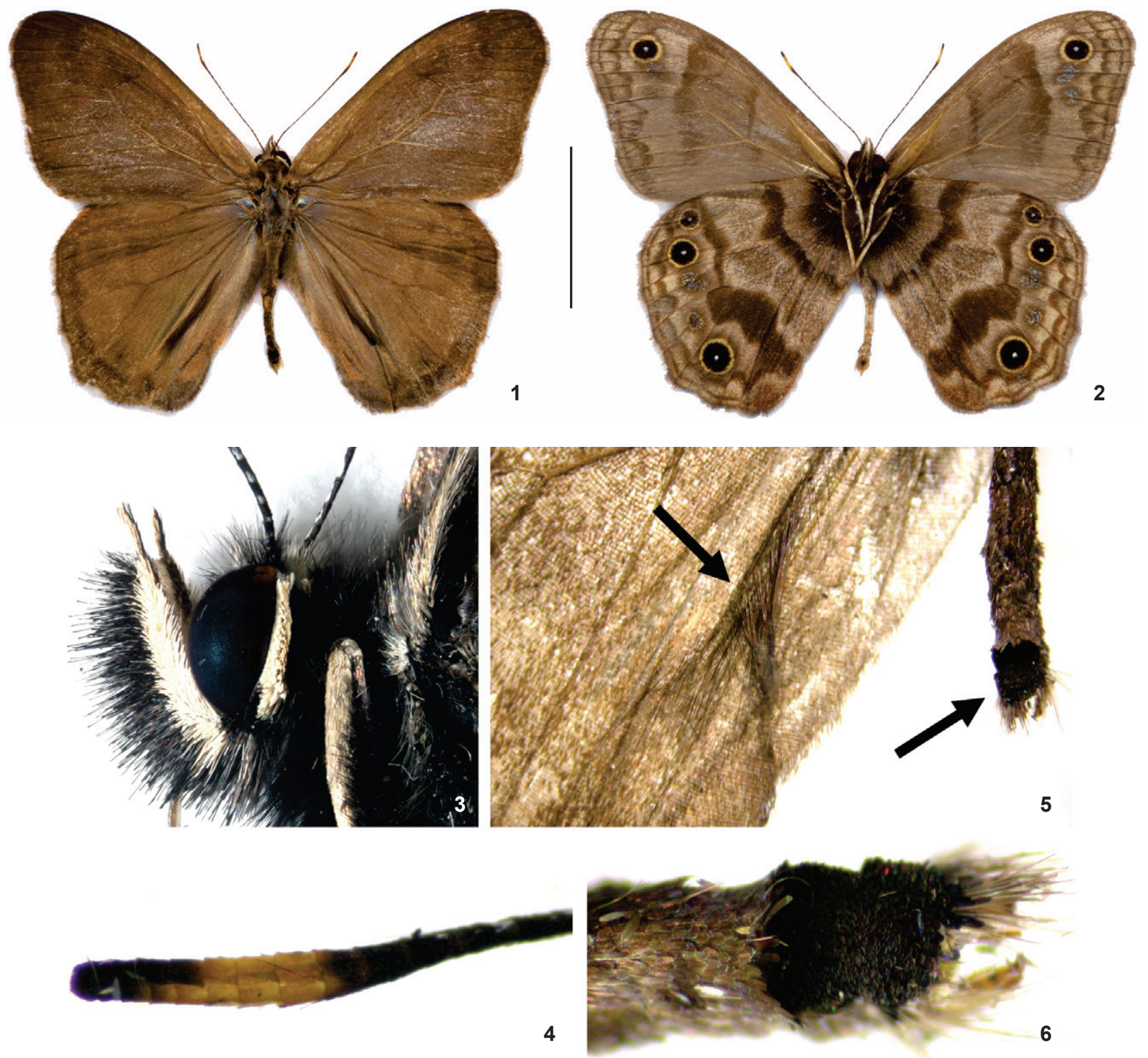

Figures 1-6. Atlanteuptychia ernestina. (1-2) Adult male: (1) dorsal side; (2) ventral side; (3-6) morphological characters: (3) eye and palpus details; (4) antenna club detail; (5) male hind wing androconial hairs (left arrow) and last abdominal segments with distinct black scales (right arrow); (6) detail of the distinct black scales covering dorsal portion of the last abdominal segments. Scale bar: 1-2 = 10 mm.

on apical abdominal segments, ground color and markings very similar to male, but most patterns paler and not well marked. Wing venation, palpus and foreleg of female illustrated in Figs 14,17 , and 18 , respectively.

Color variation. All examined individuals are quite similar, and the few observed differences are in the size and conspicuity of the irregular silver ocelli of both wings, and the shape and width of the dark brown transverse bands in HWV.
Habitat and geographic distribution. Based on all available information, A. ernestina is widely distributed in 21 sites in the Brazilian states of Santa Catarina, Paraná, São Paulo, Rio de Janeiro, Minas Gerais and Espírito Santo, mostly from well preserved areas of wet forests in the Atlantic Forest Biome (see Table I and Fig. 19). The species is more common at 800 to $1100 \mathrm{~m}$, but it is also present at the sea level on the foothills of coastal mountains in southeastern Brazil. Based on the present records, the species is considered rare, and has been seldom 

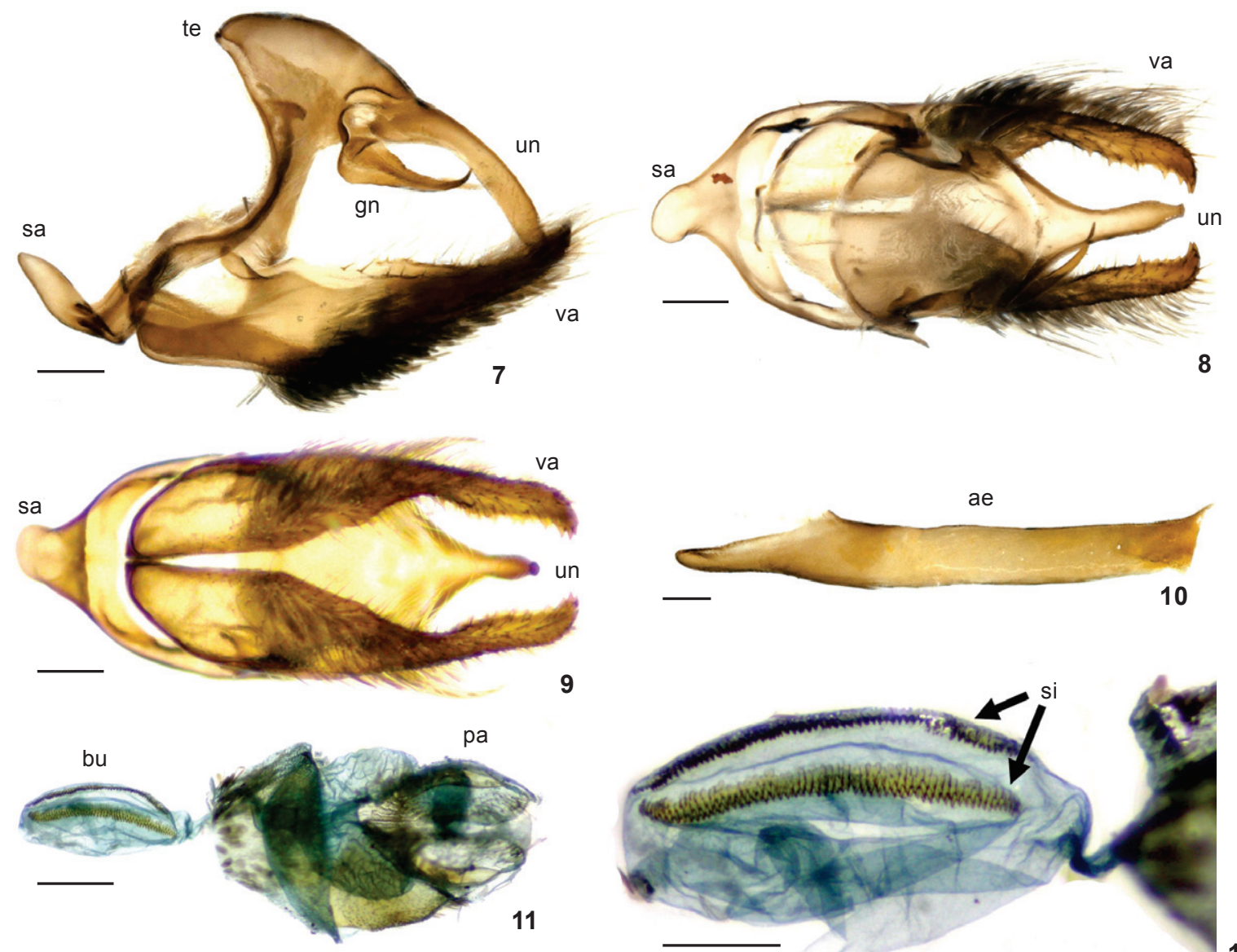

9

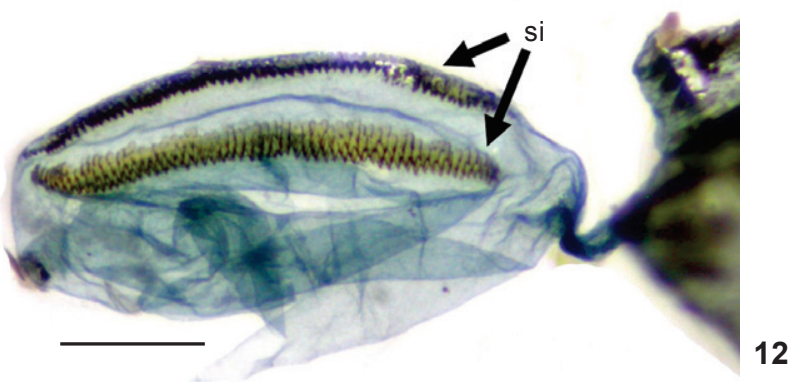

Figures 7-12. Male and female genitalia of Atlanteuptychia ernestina: (7) male genitalia in lateral view; (8) male genitalia in dorsal view; (9) male genitalia in ventral view; (10) male eadeagus in lateral view; (11) female genitalia in ventral view; (12) female genitalia: detail of the signa in corpus bursae. (sa) Saccus, (te) tegumen, (un) uncus, (va) valva, (gn) gnathos, (ae) eadeagus, (bu) corpus bursae, (pa) papillae anales, (si) signa. Scale bars: 7-9 $=0.2 \mathrm{~mm}, 10=0.1 \mathrm{~mm}, 11=0.4 \mathrm{~mm}, 12=0.25 \mathrm{~mm}$.

observed and/or collected. However, a recent study with baited traps (using banana and sugarcane juice fermented for 48 hours) in Serra do Japi (JPS and AVLF, unpub. data), suggests that it is more common than previously thought. In this locality, during 15 months of study, 12 adults were recorded ( 9 males and 3 females), 11 of which in the canopy, and only one in the understory. In previous fieldwork in the same site, only 4 individuals had been collected over 30 collecting days through 20 years (AVLF AND KeITH S. BRown JR, unpub. data). These observations suggest that $A$. ernestina may be a canopy-dwelling species, and adults are collected on rare occasions when they descend to the understory. Females are usually collected when flying low in the understory, with a behavior that resembles host-plant searching, but additional observations are needed to confirm this. There is no additional information about behavior of either males or females, and host plants are unknown.

\section{DISCUSSION}

Although having a small wingspan and a wing pattern resembling that of some dark Euptychia (e.g., Euptychia enyo Butler, 1867, and Euptychia picea Butler, 1867), the removal of A. ernestina from Euptychia is supported by morphological (present study) and molecular data (PeÑa et al. 2010). The male genitalia lacks the posterior projection of the tegumen, a structure considered a synapomorphy of Euptychia (FreITAS et al. 2012). Additionally, A. ernestina differs from all known Euptychia by the presence of a well-developed gnathos in the male genitalia (absent in Euptychia spp.), and by the absence of a recurrent vein in the FW (present in Euptychia spp.) (ForsTer 1964, Pulido et al. 2011, Freitas et al. 2012).

Based on molecular data, A. ernestina is not related to any Euptychia species, but instead, it is the sister group of a clade 
Table I. Data for studied individuals of Euptychia ernestina from seven Museum collections (see text for museum acronyms). KS Brown = unpublished record by Keith S. Brown Jr.

\begin{tabular}{|c|c|c|c|c|c|c|}
\hline Acronyms & Sex & Date & State & Municipality & Site & Altitude (m) \\
\hline $\mathrm{BMNH}$ & 1 male & - & Rio de Janeiro & - & - & - \\
\hline $\mathrm{BMNH}$ & 1 female & - & Rio de Janeiro & - & - & - \\
\hline BMNH & 1 female & VIII-IX.1884 & Rio de Janeiro & Saquarema & "Laguna de Saquarema"1 & $50-100$ \\
\hline DZUP & 1 female & 15.VIII.1953 & Rio de Janeiro & Rio de Janeiro & Santa Teresa, Lagoinha & 250 \\
\hline DZUP & 1 male* $^{*}$ & 10.III.1963 & São Paulo & Rio Claro ${ }^{1}$ & - & 600 \\
\hline DZUP & 1 female* & 10.III.1963 & São Paulo & Rio Claro' ${ }^{1}$ & - & 600 \\
\hline DZUP & 1 male & 11.IV.1971 & Rio de Janeiro & Magé & Vila Inhomirim² & $50-200$ \\
\hline DZUP & 1 male & 29.I.1968 & Rio de Janeiro & Magé & Vila Inhomirim² & $50-200$ \\
\hline DZUP & 1 male & 29.III.1969 & Minas Gerais & Itaipé ${ }^{1}$ & & 650 \\
\hline DZUP & 1 female & 29.IX.1918 & Rio de Janeiro & Rio de Janeiro & Jacarepaguá, Três-Rios & $10-100$ \\
\hline DZUP & 1 female & 20.XII.1930 & Rio de Janeiro & Engenheiro Paulo de Frontin & Fazenda Santa Bárbara & $300-400$ \\
\hline DZUP & 1 female* & 02.XI.1968 & Rio de Janeiro & Itatiaia & Serra do Itatiaia/lado sul & 1100 \\
\hline DZUP & 1 female & $10 . X .1970$ & Paraná & Paranaguá & Alexandra & 10 \\
\hline DZUP-OM & 1 female & - & Rio de Janeiro & Rio de Janeiro & - & - \\
\hline DZUP-OM & 1 male & 17.XI.1936 & Rio de Janeiro & Petrópolis & Independência & 1000 \\
\hline DZUP-OM & 1 female & 1.VIII.1983 & Paraná & Paranaguá & Alexandra & 10 \\
\hline MNRJ & 1 male & VIII.19?? & Rio de Janeiro & Rio de Janeiro & - & - \\
\hline MNRJ & 1 male & 5.VII.1938 & Rio de Janeiro & Rio de Janeiro & Gávea & $10-50$ \\
\hline MNRJ & 1 male & IX.1924 & Rio de Janeiro & Itatiaia & Parque Nacional Itatiaia & 1000 \\
\hline MNRJ & 1 male & - & Espírito Santo & Alegre & - & - \\
\hline MZSP & $1 \mathrm{male}^{2}$ & 14.VI.2010 & São Paulo & Santo André & Parque do Pedroso & 850 \\
\hline MZSP & 1 female $^{2}$ & 12.1.2009 & São Paulo & Santo André & Parque do Pedroso & 850 \\
\hline USNM & 1 female & - & Rio de Janeiro & Petrópolis ${ }^{1}$ & - & 900 \\
\hline ZUEC & 2 males & 05.III.2011 & Rio de Janeiro & Cachoeiras de Macacu & REG - Trilha Vermelha & 1000 \\
\hline ZUEC & $1 \mathrm{male}^{2 *}$ & 09.1 .2012 & São Paulo & Jundiaí & Serra do Japi & $900-1100$ \\
\hline ZUEC & 1 female ${ }^{2 *}$ & 10.XI.2011 & São Paulo & Jundiaí & Serra do Japi & $900-1100$ \\
\hline ZUEC & 2 males $^{2}$ & $08 . I X .2012$ & São Paulo & Jundiaí & Serra do Japi & $900-1100$ \\
\hline ZUEC & 2 males $^{2 \star}$ & 11.XII.2012 & São Paulo & Jundiai & Serra do Japi & $900-1100$ \\
\hline ZUEC & $1 \mathrm{male}^{2}$ & 07.IV.2002 & São Paulo & Cotia & Morro Grande & $850-950$ \\
\hline ZUEC & 1 female & 20.V.1995 & São Paulo & Santos & Vale do Rio Quilombo & $50-100$ \\
\hline ZUEC & 1 female & III.1999 & São Paulo & Atibaia & Grota Funda & 1000 \\
\hline ZUEC & 1 male $^{2}$ & 28.IX.2004 & São Paulo & São Luis do Paraitinga & Votorantim & 800 \\
\hline ZUEC & 1 female $^{2}$ & 28.IX.2004 & São Paulo & São Luis do Paraitinga & Votorantim & 800 \\
\hline ZUEC & 1 female $^{2}$ & 11.XI.2005 & São Paulo & Salesópolis & EBB - Pilões & 850 \\
\hline ZUEC & 1 male $^{2}$ & 10.X.2011 & São Paulo & Jundiaí & Serra do Japi & $900-1100$ \\
\hline K.S. Brown & 1 male & 28.VIII.1967 & Rio de Janeiro & Rio de Janeiro & Morro do Sumaré & $400-650$ \\
\hline K.S. Brown & 1 male & 16.IX.1967 & Rio de Janeiro & Rio de Janeiro & Morro do Sumaré & $400-650$ \\
\hline K.S. Brown & 1 male & 13.VIII.1969 & Rio de Janeiro & Rio de Janeiri & Morro do Sumaré & $400-650$ \\
\hline K.S. Brown & 1 female & 28.IX.1968 & Espírito Santo & Santa Teresa & Penha-Pasolini & $750-850$ \\
\hline K.S. Brown & 1 male & 4.V.1970 & Espírito Santo & Santa Teresa & Penha-Pasolini & $750-850$ \\
\hline
\end{tabular}

* Genitalia examined; 'exact site of collecting unknown; ${ }^{2}$ specimens collected with baited traps. 

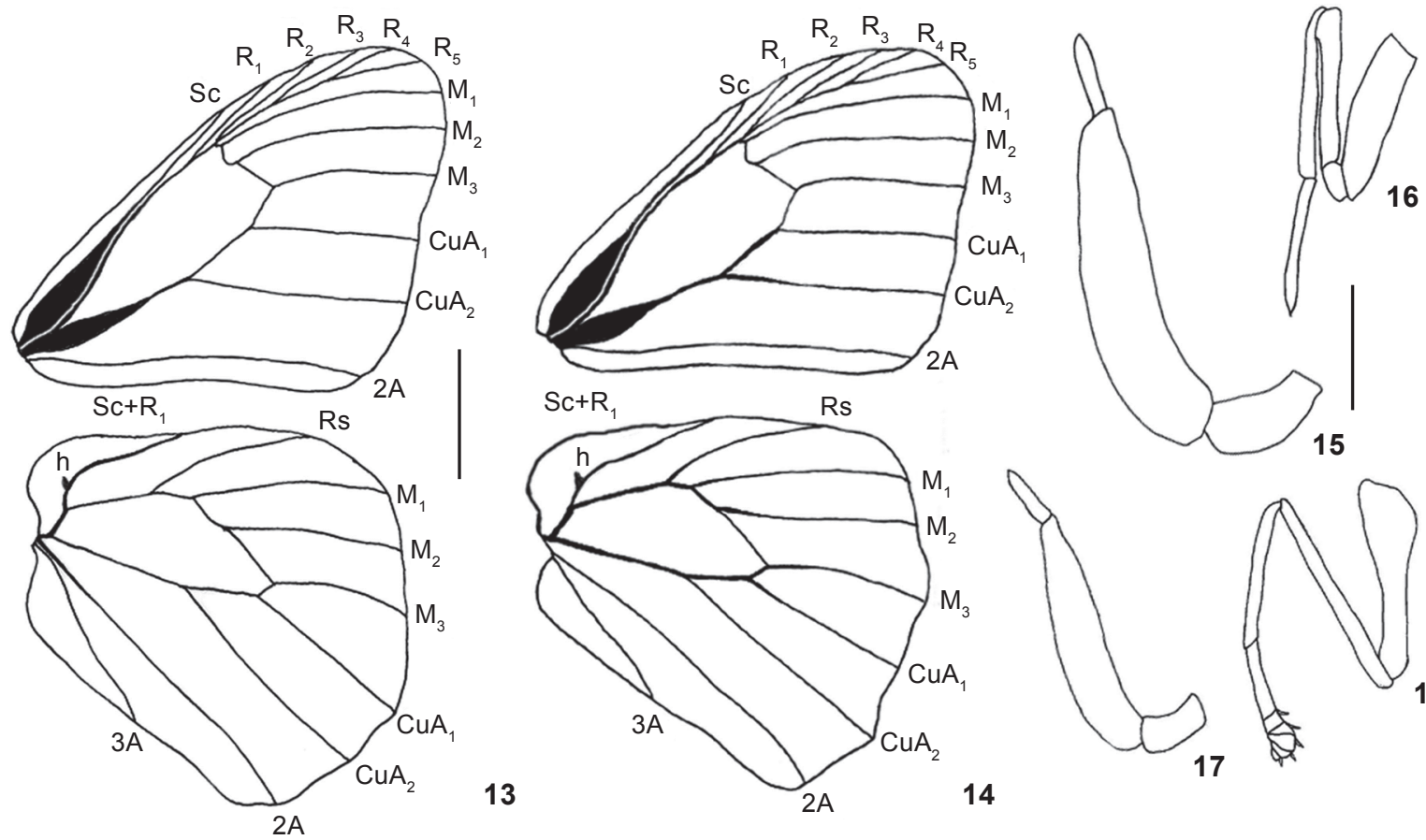

16

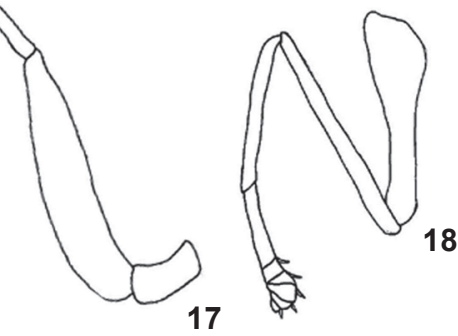

Figures 13-18. Morphological characters of Atlanteuptychia ernestina: (13) male wing venation; (14) female wing venation; (15) male palpus; (16) male foreleg; (17) female palpus; (18) female foreleg. Scale bars: 13-14 = 5.0 mm, 15-18 = $1.5 \mathrm{~mm}$.

composed by the two Central American genera, Cyllopsis R. Felder, 1869 + Paramacera Butler, 1868 (Peña et al. 2006, 2010). Peña et al. (2010) postulated that Atlanteuptychia ernestina has diverged from the ancestor of these two genera at approximately 26 mya.

Two characters of Atlanteuptychia, the conspicuous androconial tuft on the male HWD, and the distinct black scales on the abdomen, are both present in some Chloreuptychia Forster, 1964, namely Chloreuptychia catharina (Staudinger, [1886]), Chloreuptychia hewitsonii (Butler, 1867) and Chloreuptychia tolumnia (Cramer, 1777). However, in Chloreuptychia the androconial tuft is shorter and located in space $2 \mathrm{~A}-3 \mathrm{~A}$, while in A. ernestina it is longer and located in space $\mathrm{CuA}_{2}-2 \mathrm{~A}$; the distinct patch of black scales is located in the mid-ventral abdomen in Chloreuptychia, whereas in A. ernestina it is located in the last two dorsal segments.

Based on morphology only, no other euptychiine genus shows clear affinities with Atlanteuptychia, including Cyllopsis and Paramacera (the two related genera based on molecular data, see above) (AVLF and M. A. MARín unpub. data). This is quite significant from a biogeographical perspective, especially concerning the wide disjunction of Cyllopsis + Paramacera with Atlanteuptychia; while the first two genera are distributed in Central and North America, Atlanteuptychia is endemic to the Atlantic Forest.

The proposal of the new genus, Atlanteuptychia, is supported by the absence of synapomorphies uniting A. ernestina with any other known Euptychiina, including the genera
Cyllopsis and Paramacera which were considered closely related in a recent molecular phylogenetic analysis (PeÑa et al. 2010).

\section{ACKNOWLEDGEMENTS}

We thank Tomász Pyrcz (MZUJ, Kraków, Poland), Keith Willmott (McGuire Center for Lepidoptera and Biodiversity, University of Florida, USA), and Gerardo Lamas (Museo de Historia Natural, Universidad Nacional Mayor de San Marcos, Peru) for critically reading the manuscript. Jorge M. S. Bizarro helped during field work in the "Reserva Ecológica de Guapiaçu". Marcio Uehara Prado and Danilo B. Ribeiro provided specimens from Boracéia and S. L. Paraitinga, respectively, and K.S. Brown Jr provided unpublished information and helped in field work in Serra do Japi and Atibaia. The following people helped with information from the Museums: Brian Harris (USNM), Thamara Zacca (DZUP), David Lees (BMNH), Marcelo Duarte (MZSP) and Alexandre Soares (MNRJ). AVLF acknowledges the Brazilian Research Council (CNPq fellowship 302585/2011-7), and the National Science Foundation (DEB-1256742); OHHM acknowledges the CNPq for the fellowship and financial support. EPB acknowledges FAPESP (2012/03750-8), and JPS acknowledges CNPq (134982/2011-8) for graduate fellowships. This publication is part of the RedeLep "Rede Nacional de Pesquisa e Conservação de Lepidópteros" SISBIOTA-Brasil/CNPq (563332/2010-7), and of the BIOTA-FAPESP Program (2011/50225-3). 


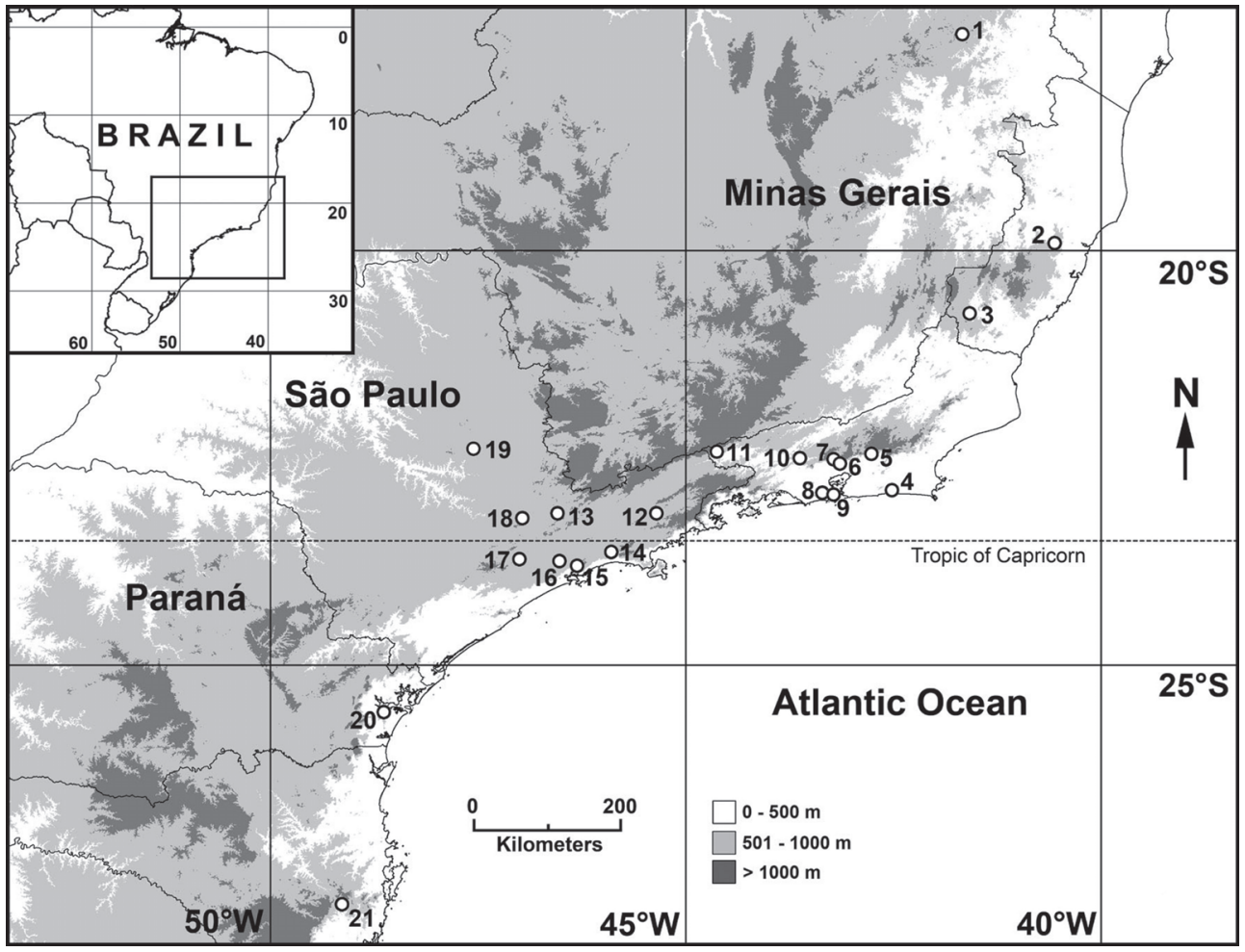

Figure 19. Map showing the 21 known localities for Atlanteuptychia ernestina: (1) Itaipé, MG; (2) Santa Teresa, including the region of Santa Leopoldina, ES; (3) Alegre, ES; (4) Saquarema, RJ; (5) Cachoeiras de Macacu, RJ; (6) Magé, RJ; (7) Petrópolis, RJ; (8) Jacarepaguá, RJ; (9) Sumaré, RJ; (10) Engenheiro Paulo de Frontin, RJ; (11) Itatiaia, RJ; (12) São Luiz do Paraitinga, SP; (13) Atibaia, SP; (14) Boracéia, SP; (15) Vale do Quilombo, SP; (16) Santo André, SP; (17) Cotia, SP; (18) Jundiaí, SP; (19) Rio Claro, SP; (20) Alexandra, PR; (21) Anitápolis, SC. See Table I for further details of each locality.

\section{LITERATURE CITED}

Brévignon, C. 2005. Description de nouveau Satyrinae provenant de Guyane française (Lepidoptera, Nymphalidae). Lambillionea 105 (3) (1): 393-404.

Brown JR, K.S. \& A.V.L. Freitas. 2000. Atlantic Forest butterflies: indicators for landscape conservation. Biotropica 32: 934956.

D'A Nymphalidae (Conclusion) \& Satyridae. Victoria, Hill House, p. 679-877.

DeVries, P.J. 1987. The Butterflies of Costa Rica and Their Natural History, Volume I: Papilionidae, Pieridae, Nymphalidae. Princeton, Princeton University Press, XXII+327p.

Forster, J.R. 1964. Beiträge zur Kenntnis der Insektenfauna Boliviens XIX. Lepidoptera III. Satyridae. Veröffentlichungen der zoologischen Staatssammlung München 8: 51-188.

Francini, R.B.; M. Duarte; O.H.H. Mielke; A. Caldas \& A.V.L. Freitas. 2011. Butterflies (Lepidoptera, Papilionoidea and Hesperioidea) of the "Baixada Santista" region, coastal São Paulo, southeastern Brazil. Revista Brasileira de Entomologia 55: 55-68.
Freitas, A.V.L.; N. Wahlberg; P.F. Matos-Maravi; M.A. Marin \& O.H.H. Mielke. 2012. Euptychia boulleti (Le Cerf) n. comb. (Lepidoptera: Nymphalidae: Satyrinae), a Rare and Endangered Butterfly from Southeastern Brazil. Neotropical Entomology 41 (6): 461-467.

GaEde, M. 1931. Satyridae. II, p. 276-476. In: E. Strand (Ed.) Lepidopterorum Catalogus 43. Berlin, W. Junk.

Hemming, A.F. 1937. Changes in the genotypes of, or in the priority to be accorded to, eleven genera of Lepidoptera, Rhopalocera, consequent upon the determination of the dates of publication of the entomological works of Jacob Hübner. Proceedings of the Royal entomological Society of London (B) 6: 149-153.

HÜBNER, J. 1818. Zuträge zur Sammlung exotischer Schmettlinge 1. Augsburg, Jacob Hübner, 40p.

Lamas, G. 2004a. Checklist: Part 4A. Hesperioidea-Papilionoidea. Gainesville, Association for Tropical Lepidoptera/Scientific Publishers, XXXVI+439p.

LAMAS, G. 2004b. Euptychina, p. 217-223. In: G. LAMAS (Ed.). Checklist: Part 4A. Hesperioidea - Papilionoidea. In: J.B. Heppner (Ed.) Atlas of the Neotropical Lepidoptera. 
Gainesville, Association for Tropical Lepidoptera/Scientific Publishers, vol. 5A, XXXVI+439p.

Le CERF, F. 1919. Description d'un genre nouveau et d'une espèce nouvelle de satyride américain (Lépidopt. Rhopalocères). Bulletin du Muséum National d'Histoire Naturelle (Paris) 25 (5): 328-329.

Marín, M.A.; C. Peña; A.V.L. Freitas; N. Wahlberg \& S.I. Uribe. 2011. From the Phylogeny of the Satyrinae Butterflies to the Systematics of Euptychiina (Lepidoptera: Nymphalidae): History, Progress and Prospects. Neotropical Entomology 40 (1): 1-13.

Peña, C. \& N. Wahlberg. 2008. Prehistorical climate change increased diversification of a group of butterflies. Biology Letters 4: (3) 274-278. doi:10.1098/rsbl.2008.0062

Peña, C.; N. Wahlberg; E. Weingartner; U. Kodandaramaiah; S. Nylin; A.V.L. Freitas \& A.V.Z. Brower. 2006. Higher level phylogeny of Satyrinae butterflies (Lepidoptera: Nymphalidae) based on DNA sequence data. Molecular Phylogenetics and Evolution 40: 29-49.

Peña, C.; S. Nylin; A.V.L. Freitas \& N. Wahlberg. 2010. Biogeographic history of the butterfly subtribe Euptychiina (Lepidoptera, Nymphalidae, Satyrinae). Zoologica Scripta 39: 243-258.
Pulido, B.H.W.; M.G. Andrade-C; C. Peña \& G. Lamas. 2011. Two new taxa of Euptychia Hübner, 1818 (Lepidoptera: Nymphalidae: Satyrinae) from the Andes of Colombia and Peru. Zootaxa 2906: 43-51.

Uehara-Prado, M.; A.V.L. Freitas; R.B. Francini \& K.S. Brown Jr. 2004. Guia das borboletas frugívoras da Reserva Estadual do Morro Grande e região de Caucaia do Alto, Cotia (São Paulo). Biota Neotropica 4 (1): 1-24.

Uehara-Prado, M.; K.S. Brown Jr \& A.V.L. Freitas. 2007. Species richness, composition and abundance of fruit-feeding butterflies in the Brazilian Atlantic Forest: comparison between a fragmented and a continuous landscape. Global Ecology and Biogeography 16: 43-54.

Wahlberg, N.; J. Leneveu; U. Kodandaramaiah; C. Peña; S. Nylin; A.V.L. Freitas \& A.V.Z. Brower. 2009. Nymphalid butterflies diversify following near demise at the Cretaceous/Tertiary boundary. Proceedings of the Royal Society of London B, Biological Sciences 276: 4295-4302.

Weymer, G. 1911. 4. Familie: Satyridae, p. 173-283. In: A. Seitz (Ed.) Die Gross-Schmetterlinge der Erde 5. Stuttgart, A. Kernen.

Appendix. The information below summarizes the current status and the systematics of Euptychia after the removal of E. ernestina (this information has been previously published with editorial errors by Freitas et al. 2012).

Euptychia Hübner, 1818

Euptychia Hübner, 1818: 20. Type-species Euptychia mollina Hübner, 1818, designated by Hemming (1937: 150).

Caenoptychia Le Cerf, 1919: 328. Type species Caenoptychia boulleti by original designation (synonymized by FreITAS et al. 2012).

Checklist of the described species and subspecies of Euptychia Hübner, 1818

Euptychia boulleti (Le Cerf, 1919)

Euptychia cesarense cesarense Pulido, Andrade, Peña \& Lamas, 2011.

Euptychia cesarense viloriai Andrade, Pulido, Peña \& Lamas, 2011

Euptychia enyo Butler, 1867

Euptychia fetna Butler, 1870

Euptychia hannemanni Forster, 1964

Euptychia hilara (C. Felder \& R. Felder, 1867)

Euptychia insolata Butler \& H. Druce, 1872

Euptychia jesia Butler, 1869

Euptychia marceli Brévignon, 2005

Euptychia meta Weymer, 1911

Euptychia mollina mollina Hübner, 1818

Euptychia mollina suzannae Brévignon, 2005

Euptychia neildi Brévignon, 2005

Euptychia picea Butler, 1867

Euptychia rubrofasciata L.D. Miller \& J.Y. Miller, 1988

Euptychia rufocincta Weymer, 1911

Euptychia westwoodi westwoodi Butler, 1867

Euptychia westwoodi muli Brévignon, 2005

Submitted: 05.IV.2013; Accepted: 07.VII.2013.

Editorial responsibility: Gabriel L.F. Mejdalani

ZOOLOGIA 30 (6): 661-668, December, 2013 